\title{
The degradation of the "Study room" (Convent of Christ, Tomar, Portugal), from a preliminary analysis towards a sustainable maintenance
}

\author{
Fernando Costa, Manuel Rosa, Mattia Canetto, Maria Júlia Sobral da Fonseca
}

\begin{abstract}
Following a comprehensive analysis of the stone degradation of the "Study Room", in the Crow's Cloister west wing (Convent of Christ, Tomar, Portugal), a multiapproach plan was made to address the salt problems encountered on its limestone columns. Chemical characterization studies were made to determine the concentration and the type of the efflorescence soluble salts involved, as well as the ionic composition of the limestone material of the column, and also, in which environmental conditions their harmful activity is reduced (or prevented). Finally, on site, the existing cement mortar was removed in a $30 \mathrm{~cm}$ area around the base of the column, and the ionic characterization obtained was submitted to the ECOS-RUNSALT software, which determined that simply by fixing the relative humidity at $65 \pm 2 \%$, the weathering process would be substantially reduced - conditions different from the ones encountered.
\end{abstract}

Keywords: limestone, column, crystallization, cellulose-pulp, salt extraction, sustainable

\section{La degradación de la "Sala de estudio" (Convento de Cristo, Tomar, Portugal), desde un análisis preliminar hacia un mantenimiento sostenible}

Resumen: Tras un análisis exhaustivo de la degradación de la piedra de la "Sala de estudio", en el ala occidental del Claustro del Cuervo (Convento de Cristo, Tomar, Portugal), se elaboró un plan de múltiples enfoques para abordar los problemas de sal encontrados en sus columnas de piedra caliza. Se realizaron estudios de caracterización química para determinar la concentración y el tipo de sales solubles de eflorescencia involucradas, así como la composición iónica del material calizo de la columna, y también, en qué condiciones ambientales se reduce (o se previene) su actividad nociva. Finalmente, en obra, se eliminó el mortero de cemento existente en un área de $30 \mathrm{~cm}$ alrededor de la base de la columna, y la caracterización iónica obtenida se sometió al software ECOS-RUNSALT, el cual determinó que simplemente fijando la humedad relativa en $65 \pm 2 \%$, el proceso de meteorización se reduciría sustancialmente, condiciones diferentes a las encontradas.

Palabras clave: piedra caliza, columna, cristalización, pulpa de celulosa, extracción de sal, sustentable

\section{A degradação da "Sala de Estudos" (Convento de Cristo, Tomar, Portugal), a partir de uma análise preliminar para uma manutenção sustentável}

Resumo: Após uma análise abrangente da degradação da pedra da "Sala de Estudos", na ala oeste do Claustro do Corvo (Convento de Cristo, Tomar, Portugal), foi feito um plano multiabordagem para resolver os problemas do sal encontrados nas suas colunas de calcário. Estudos de caracterização química foram feitos para determinar a concentração e o tipo de eflorescência dos sais solúveis envolvidos, bem como a composição iónica do material calcário da coluna, e também, em que condições ambientais a sua atividade nociva é reduzida (ou impedida). Finalmente, no obra, a argamassa de cimento existente foi removida numa área de $30 \mathrm{~cm}$ ao redor da base da coluna, e a caracterização iónica obtida foi submetida ao software ECOS-RUNSALT, que determinou que simplesmente fixando a humidade relativa em $652 \%$, o processo de intemperismo seria substancialmente reduzido - condições diferentes das encontradas.

Palavras-chave: calcário, coluna, cristalização, polpa de celulose, extração de sal, sustentável 


\section{Introduction}

The action of soluble salts in building materials is one of the main causes of monument deterioration, in the most diverse environments. Natural stone can contain water with soluble salts trapped in the pores. Most of these, move invisibly through the solution and moisture cycle, and are absorbed by the petrous material through the pores. Others, too many to keep moving, simply appear on the surface as white or gray efflorescence. Investigations about this field have ascribed the process to the pressure of growing neoformed crystals on the walls of porous systems in the building materials (Aires Barros 2002: 3-9; Cardell et al. 2003: 165-179; Franceschi and Germani 2005 : 176-178; Tsui et al. 2003: 109-115).

The alternating processes of salt dissolution, crystallization and hydration can modify the structure of rocks (Arnold and Zehnder 1990: 31-58; Fitzner 1994: 43-54; Lubelli and Hees 2007: 223; Winkler 2013: 155-156).

The crystallization process generates a high stress resulting in micro cracks causing various macroscopic changes including loss of cohesion between grains, scaling, cracking and fracturing, among others (Benavente et al. 2004: 113-127; Cardell et al. 2003: 165-179; Charola 2000: 327343; Doehne et al. 2001). The shape and extent of damage depend on the porosity and hygroscopicity of the material (Franzin 2009: 12).

This crystallization of stone salts is probably the most important factor governing stone weathering in temperate climates, as the portuguese. These salts are mainly constituents of the rocks used in the heritage (Honeycombe 1990: 153-178) but can also have anthropogenic origin (Brimblecombe and Grossi 2007). The prediction of the behaviour of a salt in a rock depends on the rock and salt physicochemical properties and on the environmental temperature and the relative humidity (\%HR). Phase change cycles play a major role on the salt crystallization and dissolution that promotes stone weathering (RuizAgudo et al. 2010) and the study of these cycles has been individually made in laboratory since the XIXth century (Goudi and Viles 2008: 129-164) but in reality, in the rocks, there are mixed salt systems organized in many possible combinations and concentrations and its crystallization and dissolution sequences are more complex, and, its empirical prediction is far from a trivial task (Steiger and Heritage 2012). The development of the ECOS software was based in the quantitative analysis of the most important cations and anions of the rock and in a thermodynamic model that could predict the environmental conditions that would minimize salt weathering of the stonework (Price 2007: 369-374). This ECOS (Environmental Control Of Salts) thermodynamic model, describes the behaviour of salts in solution relating it to temperature and relative humidity, was later upgraded in terms of the development of a graphical user interface that became known as "RUNSALT" (Bionda 2005: 2002-2005). The ECOS-RUNSALT computer program was used to predict the environmental conditions in the "Study Room" that would prevent or restrict further weathering of the studied column.

This paper reports the practical procedures taken, which were aimed at fully understand how the current state of the supported columns of the "Study Room" (Figure 1) was reached, starting from an overall historical background and going through several confluent aspects to its current situation. In fact, for an accurate analysis and for the achievement of reliable results, it is necessary to widen the review in order to include the viewpoints of several disciplines including: Architectural Heritage, Conservation and Restoration of stone materials, Mineralogy, Petrology and Chemistry. Ultimately, it was intended, with the understanding thus acquired, to minimize the process that led to the degradation of the stone, due to the crystallization of soluble salts. [Figure 1].

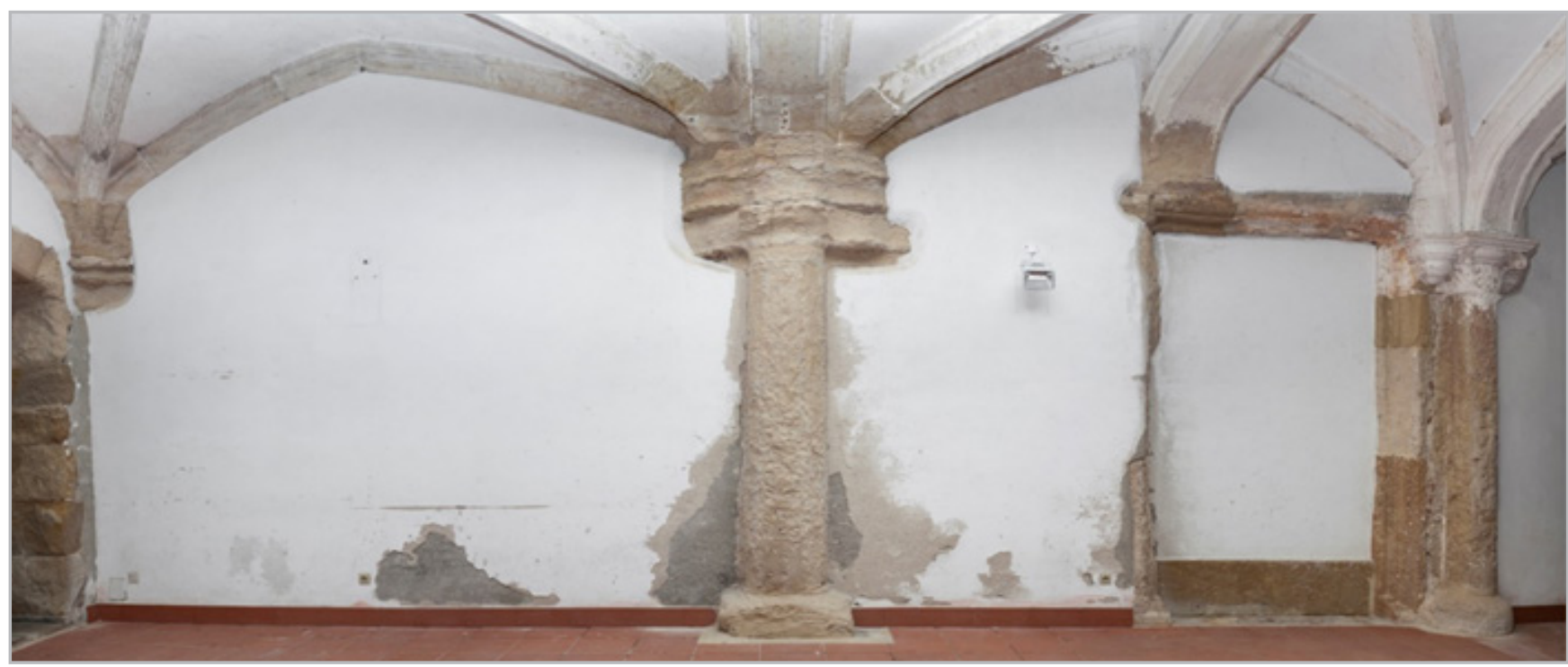

Figure 1.- Overview of the "Study Room" wall with the column under study in the centre. 
The supported column seen in Figure 1 is in the "Study Room" which is located in the west side of the Crow's Cloister, between the coffee shop and the cloister entrance. This room has two entrances: from the west gallery of the cloister and from the Executioners Courtyard.

The used methodology is based on literature review comparison with similar cases, multidisciplinary scientific knowledge, and takes into account the principles of Conservation ethics and it aims at the safeguard of the historical and cultural values of this landmark. The principles of distinctness, reversibility and of minimal intervention were taken into account in the planning of this intervention, according to a methodological process developed in such a way as to allow the transmission of the cultural asset to the future generations without delete or alter the downfall of time, in this case, special attention was paid to guaranteeing its preservation and extends its durability, by means of the most minimalist intervention possible.

To lighten this document, the technical procedures for the site conservation are only briefly mentioned to contextualize the study in the context of the emerging intervention.

\section{From diagnosis to action}

This limestone column is $3.5 \mathrm{~m}$ high in total. Its petrous material was in an advanced state of degradation caused by cement mortar ancient repairs, followed by efflorescence and erosion as shown in Figure 2. Humidity stains, pulverization and cracks were also noticeable, all, important anomalies to the material, as for the normal and healthy use of the room; in addition to the aesthetic degradation, loss of historical material was reported. Hence, the reduction of the mechanical strength of the materials and the construction elements (Puim et al. 2012 : 2). The phenomenon was found very worrying in all perspectives. [Figure 2]
Another factor that influenced the formation of efflorescences and especially their migration to the surface of the column is the presence of two layers of cement mortar. This is incompatible with the masonry of limestone. In fact, during the 20th century, in the restoration of masonry structures, there was a tendency to replace mortars with cement-based mortars. However, in several recent cases, extensive damage to the ancient masonry due to incompatibility of the cement-based mortars with the old materials has clearly been established. Indeed, cement-based mortars show a high content of soluble salts, potentially dangerous for decay of ancient mortar by crystallization and dissolution cycles (Lanas and AlvarezGalindo 2003: 1867). In fact, the saline efflorescence was more abundant in the interface cement/column than in the central area of the column.

Meanwhile, starting the conservative intervention, the inadequate material has been removed, namely, the cement mortar around the perimeter of the column, reaching a distance of about $30 \mathrm{~cm}$ as presented in Figure $3 a$.

Given the seriousness of the degradation observed and its causes being obvious, the recording of environmental conditions and sampling (under the required conditions) were immediately started, which would allow the harmful influence of salts on the stone to be quantified and qualified.

Thus, in order to characterize the environmental conditions, the surface humidity was measured in loco and a datalogger was installed for continuous measurement of the temperature and relative humidity in the compartment; for the characterization of the salts observed on the surface, samples were immediately collected with scalpels and a plan for collecting soluble salts with cellulose pulp was established - which would allow, not only remove them, but also monitor the effectiveness of the procedure
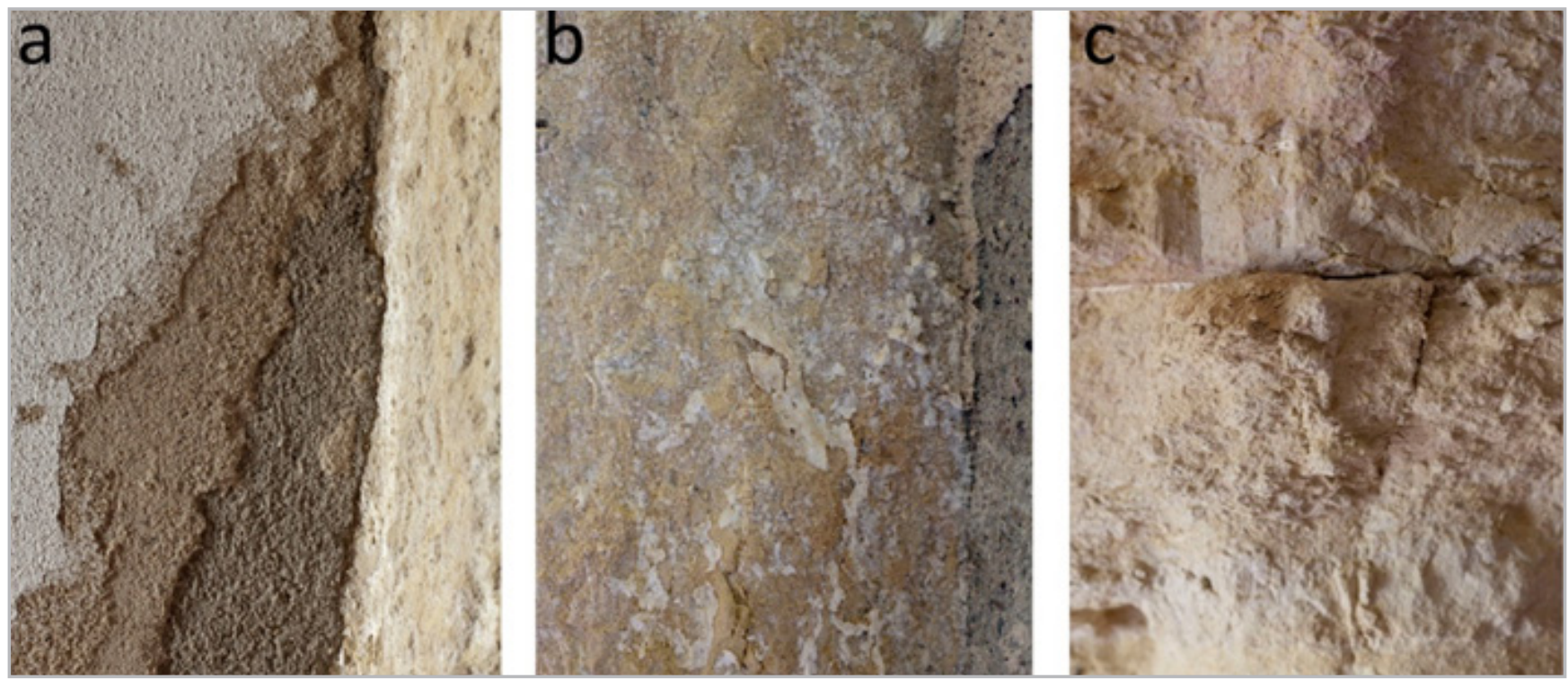

Figure 2.- Stone deterioration of the column: (a) cement mortar layers, (b) efflorescences and (c) erosion. 
until it becomes essential redundant, both, in 13 preestablished subdivisions of the most affected column; thirdly, two drilled samples were taken from the column's base, to investigate the specific composition of this rock (cations and anions), which would be available to recombine as a result of the climate conditions scenarios suggested by ECOS-RUNSALT.

Additionally, it was decided to collect involuntary samples of stone from the column, whose diffraction analysis would establish the mineralogical composition of this particular limestone.

\section{Methodology}

Meanwhile, starting the conservative intervention, the inadequate material has been removed, namely, the cement mortar around the perimeter of the column, reaching a distance of about $30 \mathrm{~cm}$ as presented in Figure $3 \mathrm{a}$.

\section{-Climatic study}

\section{- Column surface moisture}

The analyses of the humidity present in the limestone, measured with the use of a portable Protimeter Mini Super Mk2, were carried out with a total of 13 measurements at the mentioned reference distances, both in sunny and rainy days, in order to observe the existing differences under those environmental conditions.

\section{- Environmental parameters's automatic measurement}

The environmental thermo-hygrometric conditions of the "Study Room" were monitored since October 2012 to June 2013 < . For the monitoring (hourly), a datalogger type Rotronic Hygrolog D High Precision ( $\pm 1.5 \% \mathrm{RH}$ accuracy) was used, being placed in the center of the room at a height of about $3 \mathrm{~m}$. The monitoring campaign focused on the measurement of the two most important parameters that influence the weathering of the stone materials in the room: Temperature $(\mathrm{T})$, in ${ }^{\circ} \mathrm{C}$ and Relative Humidity (HR), in \%. The air temperature and the relative humidity values strongly influence also the crystallization of soluble salts (Arnold and Zehnder 1990 : 31-58).

The factors that affect the amount of absolute humidity and water vapor present in the room environment are:

a) Outside weather conditions of temperature and relative humidity;

b) The periodic openings of the doors, with the resulting mixing of internal and external air.

The standard UNI 10829:1999 (Norma UNI 10829:1999: 1-20) suggests, for the conservation of porous stones, a relative humidity value that ranges from $40 \%$ to $60 \%$ and a temperature value that ranges from $15^{\circ} \mathrm{C}$ to $25^{\circ} \mathrm{C}$ but it all depends on the stone base material ionic composition.

\section{- Salt/lonic study}

- Soluble salts

-Mechanically collected (scalpels)

Following the column vertical profile, sections were established at distances of $20 \mathrm{~cm}$, from the base up to the chapiter. This subdivision was necessary to have physical references and understand the distribution and the vertical pattern of the salts, both qualitatively and quantitatively, allowing to know with precision the behavior of the different species of salts, and to assume their origin.

With these reference distances, 13 samples of saline efflorescence were collected using a scalpel. The samples, once detached from the support, were kept individually in plastic bags marked with the labels corresponding to the intervals of distance and then sealed.

The chemical analyses were conducted in order to quantify the soluble salts, in the form of the concentration of the respective ions after solubilization. The samples were collected along the entire profile of the column. The concentrations of the soluble salts were determined after the dissolution of the efflorescence in water. The chloride concentration was obtained by a volumetric method (Mohr method), the determination of the sulphate concentration was obtained by a turbidimetric method (Standard Methods 9038) and the nitrate concentration was obtained by the use of a photometric absorption method (Dimethylphenol Method).

\section{-Removed by the application of cellulose patches}

It was also decided to take advantage of the removal of salts with cellulose pulp patches (CR methodology for the partial removal of salts from porous materials, but, before the extraction of the salts, it was necessary to proceed with the mechanical removal of the efflorescences, visible and scarcely adherent to the surface, by the use of soft toothbrushes, scalpel, in such a way as to avoid their solubilization and possible penetration into the limestone. Subsequently, all the residues on the stone were removed by compressed air, using an adequate pressure in order not to damage furthermore the column. [Figure 3]

The method used for the removal of the soluble salts was the application of multiple consecutive patches of cellulose pulp (free of soluble salts) and deionized water, since the use of absorbent clays have the drawback of subtracting the water too quickly not given enough time to the salts to dissolve (or solution to penetrate), restricting the effectiveness of the subsequent drying 


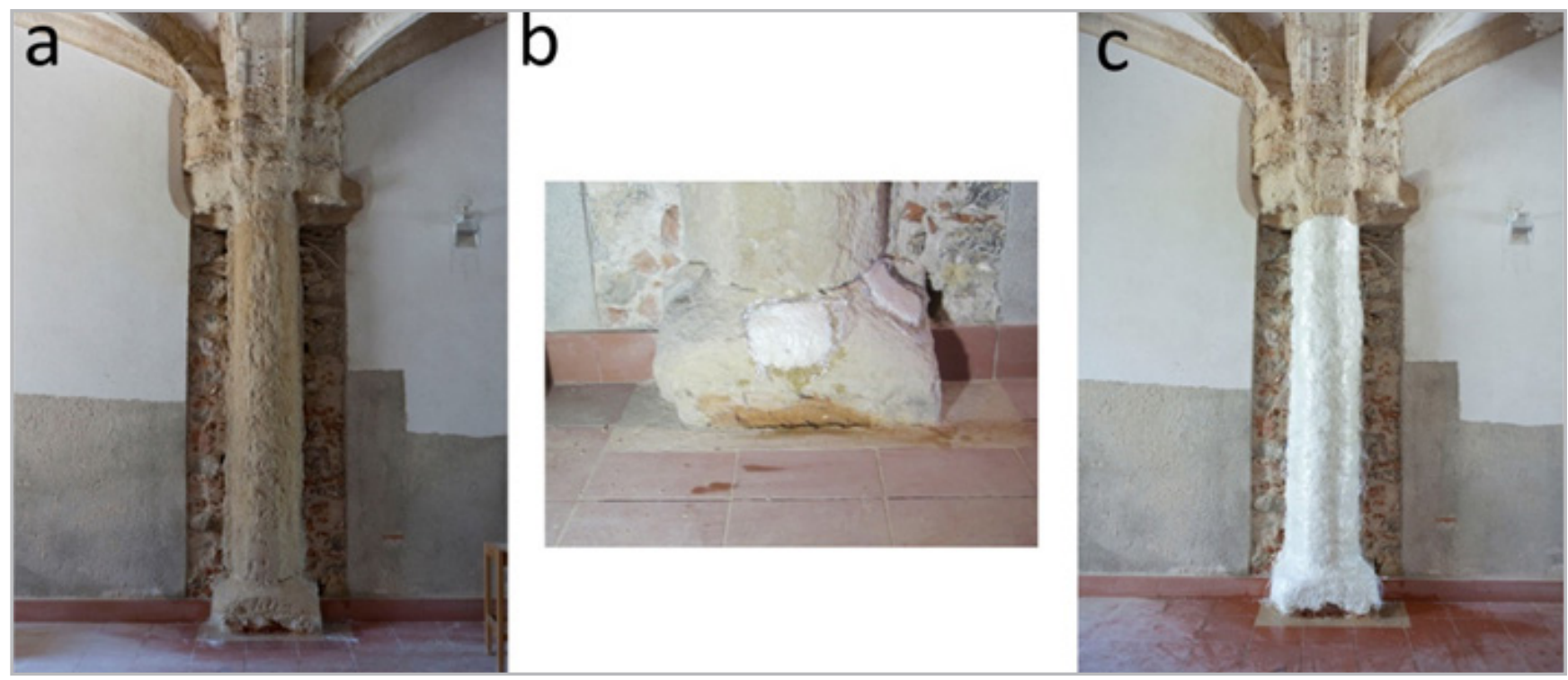

Figure 3.- Intervention of conservation; (a) removal of cement mortar, (b) the preliminary test of absorption with cellulose pulp ARBOCELL BC1000 and (c) the cellulose pulp applied over the entire surface of the column.

step; in which the water carries the dissolved salts towards the pulp, extracting them from the limestone.

The time of application of the pulp was based on a preliminary test carried out (Figure $3 \mathrm{~b}$ ) on a portion of the surface (about 10x10 cm) and its duration was influenced by the time necessary to allow the pulp to dry (Franceschi and Germani 2005 : 176-178). Following the satisfactory results of the tests, absorbent pastes were applied over the entire surface of the column, as presented in Figure $3 c$. The extraction of soluble salts was performed in three cycles by applying the pulp (ARBOCELL BC1000, average fiber length $700 \mu$ ), to the entire surface of the column and respective chapiter, allowing every cycle to perform extraction during of 48 hours. After each cycle, the pulps were removed at intervals of $20 \mathrm{~cm}$ with the help of scrapers, separated and taken to the laboratory where their conductivity was measured.

\section{Practical Procedures:}

1) The pulps plasters were prepared by mixing $50 \mathrm{~g}$ of cellulose pulp with $200 \mathrm{ml}$ of distilled water and were placed in selected areas, leaving them to act for a time of 48 hours. They were covered with plastic film to prevent its detachment and to avoid the quick evaporation of the water.

2) Once dried, the pulps were removed and taken to the laboratory where they were allowed to dry in an oven, placed inside suitable containers for 6 hours at $105^{\circ} \mathrm{C}$ (to achieve a constant weight) and after cooling in a desiccator, their weight was measured.

3) In order to measure the specific conductivity, the pulp plasters extracted were immersed in a suitable volume of deionized water ( 1 liter) with conductivity not exceeding a few units of $\mu \mathrm{S} / \mathrm{cm}$. After homogenizing the suspension, it was measured the conductivity. The specific conductivity was measured by means of a conductivity meter with automatic temperature compensation.

\section{- Ionic composition}

The samples collection was made by drilling $2 \mathrm{~cm}$ into the column in a lateral face of its base structure. Three samples were collected and ground in a ball mill prior to the salt extraction.

The extraction process of the water-soluble salts was done with distilled water in a proportion of $0,1 \mathrm{~g}$ of ground sample per $10 \mathrm{ml}$ of distilled water. The time of extraction was 24 hours.

The dissolved salts enable the quantification of the ion concentration in the extracted solution. The ions quantified were $\mathrm{Cl}^{-}, \mathrm{NO}_{3}{ }^{-}, \mathrm{SO}_{4}{ }^{2-}, \mathrm{Na}^{+}, \mathrm{K}^{+}, \mathrm{Mg}_{2}{ }^{+}$and $\mathrm{Ca}_{2}{ }^{+}$. This ion analysis was performed at the IST (Instituto Superior Técnico) Analysis Centre in Lisbon, using for the anions analysis the APHA Method 4110 (APHA 1992) by ion chromatography and for the cation analysis the "ISO 11885:2007 by inductively coupled plasma optical emission spectrometry (ICP-OES).

\section{-Mineralogical study}

The X-ray diffraction analysis (XRD) with diffractometer Rigaku Last IV was carried out to recognize the mineralogical species present in the samples of the salts taken from the surface of the column. Specifically, the analyzed samples were taken at the distances $0-20 \mathrm{~cm}, 80-100 \mathrm{~cm}, 160-180$ $\mathrm{cm}$ and $240-260 \mathrm{~cm}$ from the base of the column. 


\section{Results and discussion}

\section{- Climatic characterization}

- Column surface moisture, results

The measurements on the column surface humidity were almost always of $100 \%$, and in relation to this parameter, the influence of the outside atmosphere is plausible through the doors, but the importance of the nearby Crow's cistern is ruled out.

The higher humidity values in the upper part of the column (chapiter), as shown in Figure $4 \mathrm{e}$, are probably due to the infiltrations originated from the terrace situated above the room.

- Environmental parameters' automatic measurement, results

The monitoring of the "Study Room" microclimate is presented in the chart of Figure 4 where the temperature and relative humidity appear in function of time from early November to mid-June. The temperature did not have large variations in January and February but it clearly decreased in November and December and increased in March, April and June. The average temperature during the monitoring campaign was $15.0^{\circ} \mathrm{C}$ with a maximum of $20.5^{\circ} \mathrm{C}$ and a minimum of $11.9{ }^{\circ} \mathrm{C}$. The relative humidity presented higher variations with an average of $65.7 \%$, a maximum of $87.1 \%$ and a minimum of $41.0 \%$. [Figure 4 ]

\section{- Salt/lonic characterization}

- Soluble Salts

\section{- Mechanically collected (scalpels)}

The values obtained for concentration of the analyzed ions presented in the efflorescences are shown in the charts of Figure 5. They reveal that the chloride salts have values about one thousand-fold higher compared to the sulfate and nitrate salts.

The profile of the distribution of the chloride salts on the surface of the column was mainly constant and this phenomenon is explained by the higher solubility and greater mobility of these salts compared to the other studied salts. The lowest obtained value of chloride ion concentration was $0.337 \pm 0.018 \mathrm{~g} / \mathrm{l}$ on the base of the column and the highest values on the lower half of the column ranging from $1.335 \pm 0.057 \mathrm{~g} / \mathrm{l}$ at $60 \mathrm{~cm}$ from the base to $2.245 \pm 0.051 \mathrm{~g} / \mathrm{l}$ at $140 \mathrm{~cm}$ from the base.

The concentration of the nitrate ion was higher on the base of the column with values of $10.029 \pm 0.81 \mathrm{mg} / \mathrm{l}$ and $9.804 \pm 0 \mathrm{mg} / \mathrm{l}$ at $20 \mathrm{~cm}$ from the base, the lowest value was $0.257 \pm 0.107 \mathrm{mg} / \mathrm{l}$ at the top of the column $(240 \mathrm{~cm})$, this may be explained by the use of this room as a stable for some time in the past.

As to the sulphate ion, the obtained concentrations have an out-of-trend peak in the body of the column, at a height of $60 \mathrm{~cm}$ reaching the $13.858 \pm 0.082 \mathrm{mg} / \mathrm{l}$ mark but the general trend is clearly of a decrease towards the top of the column starting at the bottom of the column with a concentration of $10.205 \pm 0.137 \mathrm{mg} / \mathrm{l}$ and decreasing to $0 \mathrm{mg} / \mathrm{l}$ at the top of the column. This may be explained by the contact of the limestone column material with the cement mortar applied in the past at its base with a wave of sulphates progressing towards the top of the column.

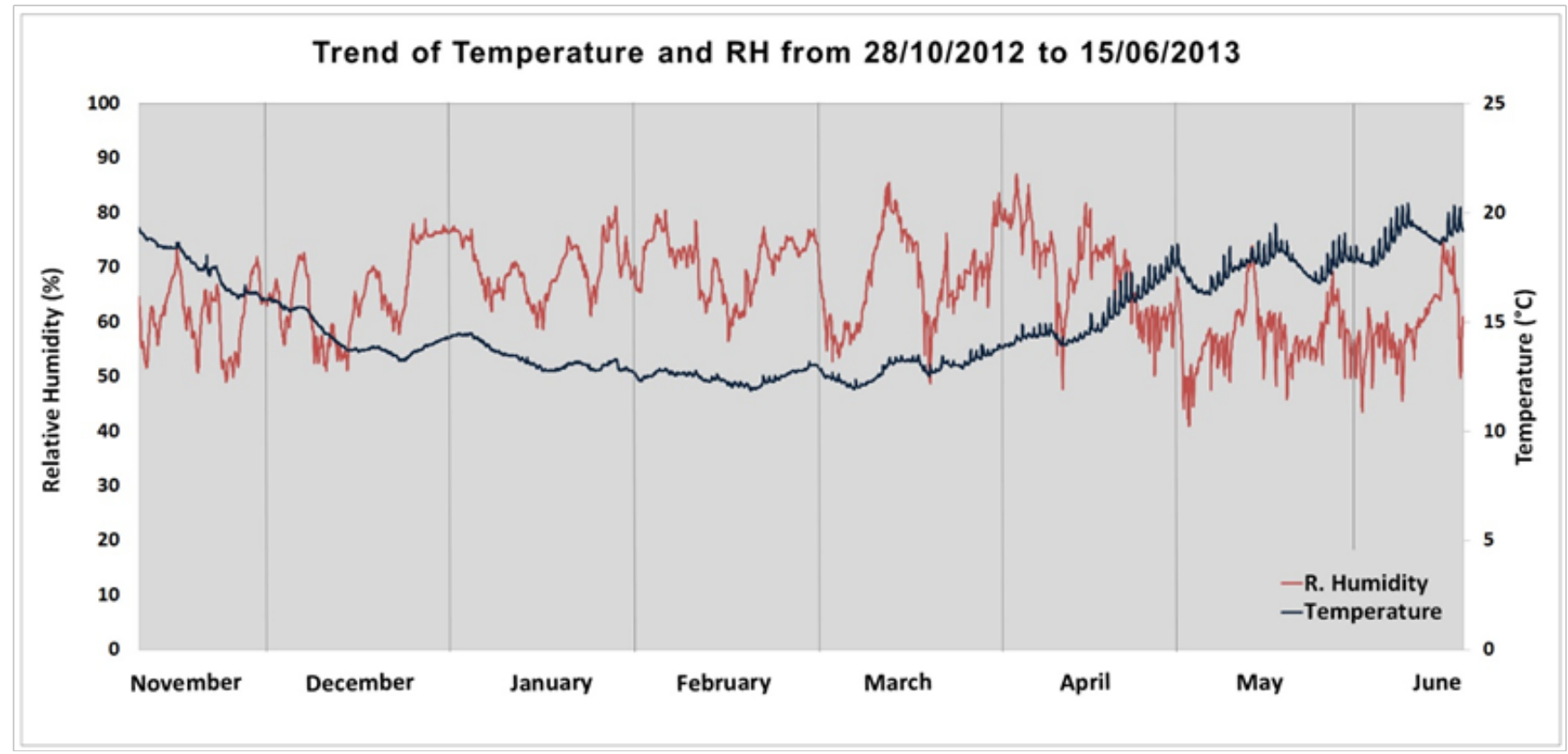

Figure 4.- Trend of Temperature and Relative Humidity of the "Study Room". 
- Removed by the application of cellulose patches

Relative to the intervention, the obtained values on the three tests show a significant decrease of the conductivity from 2540 to $371 \mu \mathrm{S} / \mathrm{cm}$ in the case of the central sample and from 3116 at $490 \mu \mathrm{S} / \mathrm{cm}$ in the case of the sample on the right side. The cycles of absorption gave satisfactory results. The cycles of absorption were monitored by the analysis of the conductivity and revealed higher salt extraction at the base of the column, decreasing upwards, with lowest values at the top of the column. These results are in general accordance with the specific individual determination of the concentration of the three studied ions. From the first to the third application, in the base, the initial values that were close to $9000 \mu \mathrm{S} / \mathrm{cm}$ fell to values close to $500 \mu \mathrm{S} / \mathrm{cm}$ and, at the top, from values close to $5000 \mu \mathrm{S} / \mathrm{cm}$ to $600 \mu \mathrm{S} / \mathrm{cm}$, as can be seen in Figure $5 \mathrm{~d}$. A considerable quantity of salts was absorbed from the surface of the column. Also, the appearance of the stone improved. [Figure 5]

- Ionic Composition

The results obtained from the ion analysis are presented in the Table 1.

\begin{tabular}{|c|c|c|}
\hline lons & Original (ppm) & $\mathrm{Sd}$ \\
\hline $\mathrm{Cl}^{-}$ & 9.67 & 1.53 \\
\hline $\mathrm{SO}_{4}^{2-}$ & 10.67 & 1.53 \\
\hline $\mathrm{NO}_{3}^{-}$ & 3.00 & 0.00 \\
\hline $\mathrm{Na}^{+}$ & 9.67 & 1.15 \\
\hline $\mathrm{K}^{+}$ & 13.00 & 7.81 \\
\hline $\mathrm{Mg}^{2+}$ & 4.43 & 0.67 \\
\hline $\mathrm{Ca}^{2+}$ & 110.00 & 10.00 \\
\hline
\end{tabular}

Table 1.- The ionic composition of solutions obtained from the dissolution of the salts contained in the limestone material of the column and its standard deviation (sd).

\section{- Mineralogical characterization}

The diffractograms obtained and presented in Figure 6, were all very similar. The spectra showed the presence of calcite and halite at all heights. The calcite is attributable to the type of limestone composition, while the halite, a sodium chloride mineral, may be related to the casual presence of chloride salts. [Figure 6]

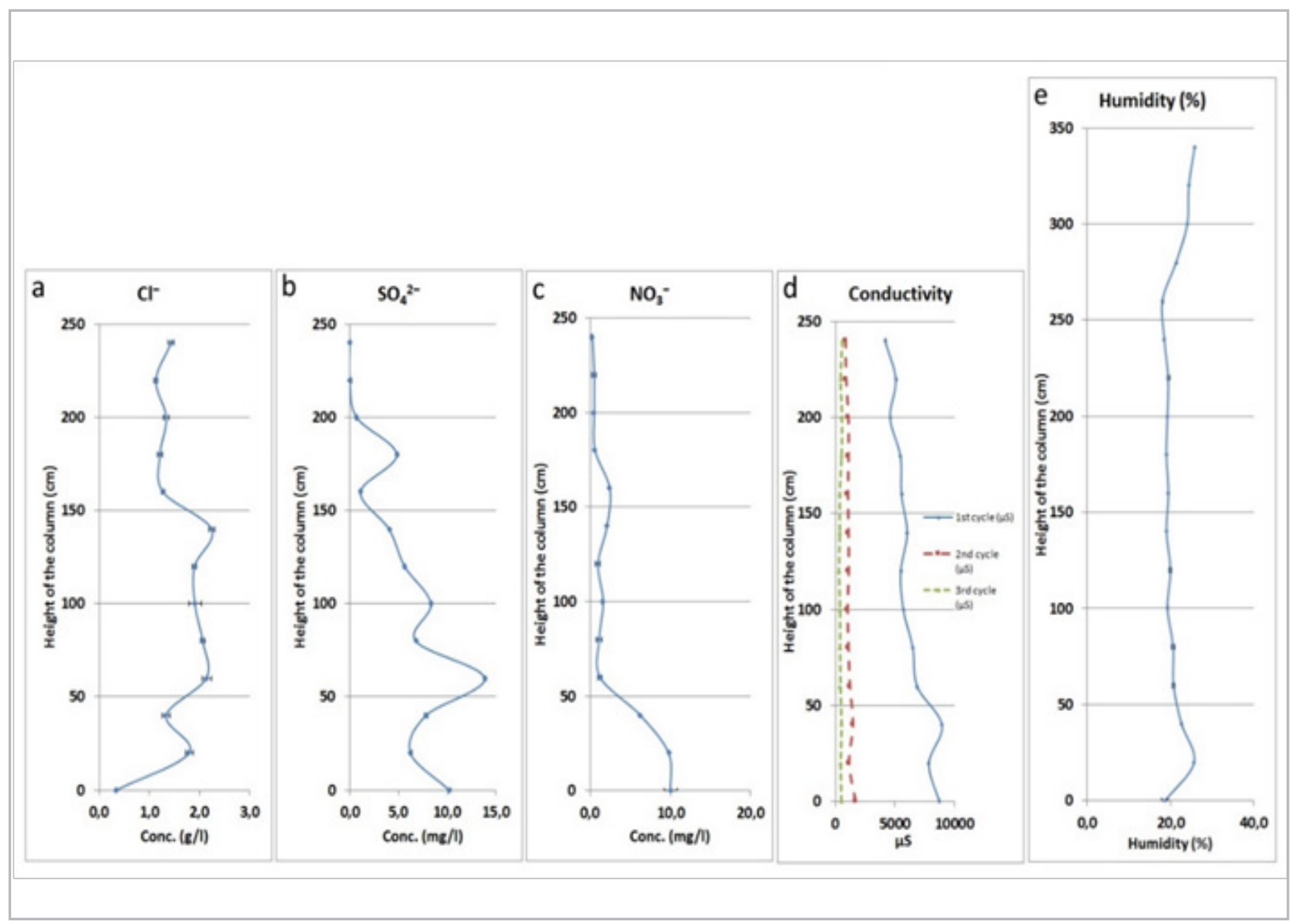

Figure 5.- Reference distances and respective distribution of the concentrations of (a) chlorine ion, (b) sulphate ion and (c) nitrate ion in the efflorescences, (d) conductivity of the cellulose after the tree interventions cycles and (e) surface humidity of the column limestone. 


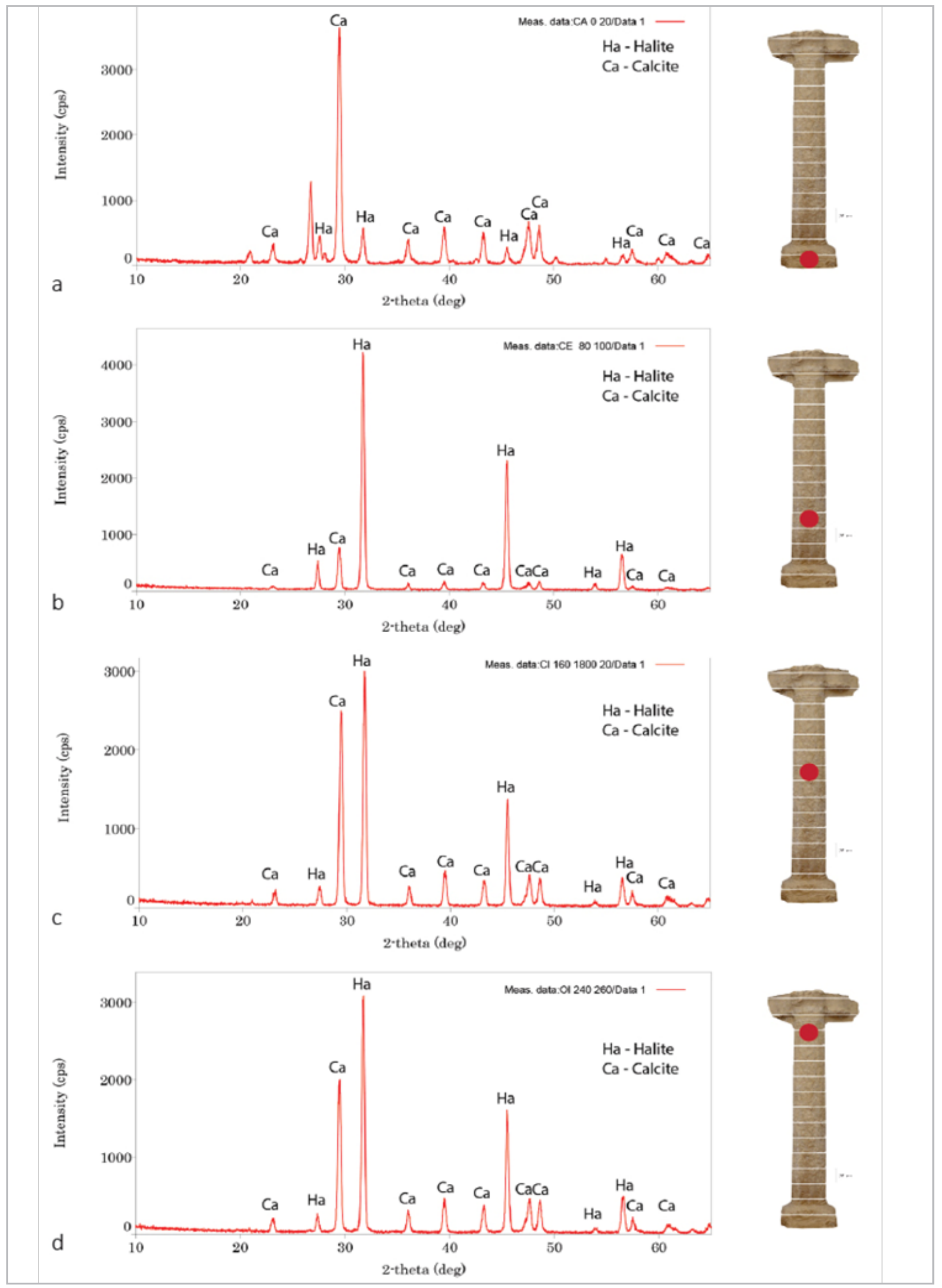

Figure 6.- XRD Spectrums of saline efflorescence from the base (a) to the top of the column (d). 
Sodium chloride is the main salt in maritime aerosols, and it can be found in the atmospheric deposition at distances of up to $100 \mathrm{~km}$ from the coast. In many cases, this type of weathering can be so serious that it results in the loss of the architectural and historical value of a building or monument (Silva et al. 2007). In this case, in the column base sample, the highest halite peak is very weak. Meanwhile, the same peak is of about the same heigh and area on the other three samples of the column. The other two halite peaks give analogue information for the base and remaining three samples. This information, is in accordance with the general profile of the previous determined chloride ion concentrations.

\section{- The ECOS-RUNSALT software}

The ECOS-RUNSALT program performed the necessary calculations for the corrections of the concentration of $\mathrm{Ca}^{2+}$ and gypsum $\left(\mathrm{CaSO}_{4} 2 \mathrm{H}_{2} \mathrm{O}\right)$, after which the environmental parameters were set for a relative humidity between $15 \%$ and $98 \%$.

The simulations were done for different values of environmental temperature ranging from 0 to $40{ }^{\circ} \mathrm{C}$ with a 5 ${ }^{\circ} \mathrm{C}$ step. Figure 7 shows, as examples, the evolution of the salt composition volume obtained with ECOS-RUNSALT for three of the studied temperatures $\left(0,15\right.$ and $\left.30^{\circ} \mathrm{C}\right)$, being the black line the sum of the volumes of all the salts present according to the program calculations. The charts give us information about the salt volume variations.

Analysing the information enclosed in the chart for $0{ }^{\circ} \mathrm{C}$, we can see that when relative humidity rises, occurs dissolution of the salts. In detail, at about $25 \%$ of relative humidity, the calcium nitrate dissolves totally and antarcticite starts a process of dissolution that ends at about 33\% of relative humidity. Carnallite starts dissolving also at $25 \%$ of relative humidity but the process is slower and only ends with the total vanishing of its crystalline form at about $43 \%$. The other two salts present are sylvite and halite and remain in its crystalline state until $63 \%$ of relative humidity. Looking at the chart in reverse direction, for $0{ }^{\circ} \mathrm{C}$, the constant decline in relative humidity produces an increase in the volume of crystallized salts from $63 \%$ until $25 \%$ of relative humidity. Only when the relative humidity declines, the conditions for the expansion of salts (increase in salt volume) arise and thus for the occurrence of limestone weathering of this base material of the column.

The salt behaviour also depends on the temperature, and thus other temperatures were studied and as the example of Figure 7 shows, the crystallization/dissolution processes have different curve profiles as the relative humidity changes. It also shows that the relative humidity conditions that promote salt crystallization indicate that, according to the "Study room" climatic study, the main salt to crystallize is halite, in accordance with the results of the XRD Spectrums. [Figure 7]
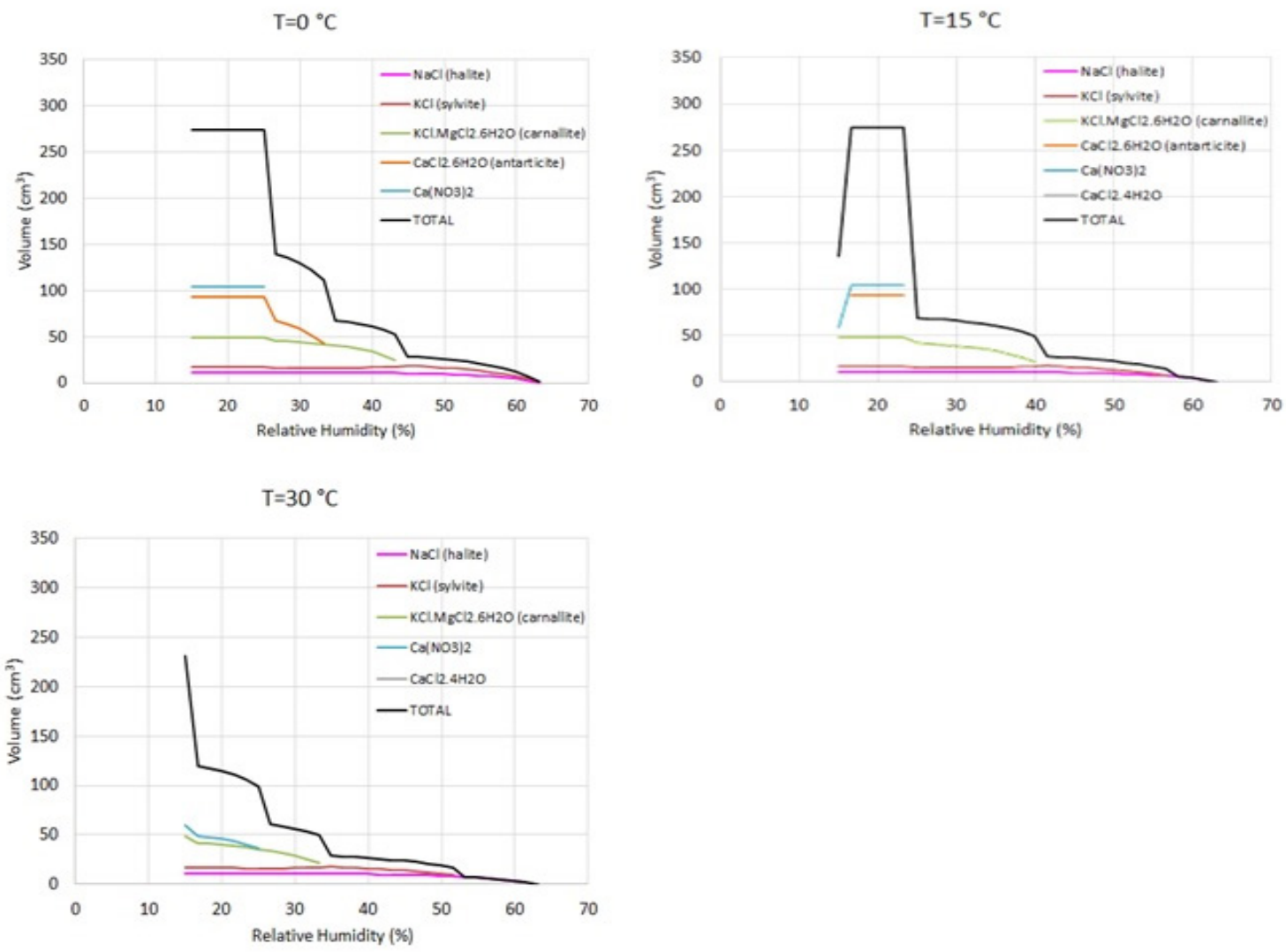

Figure 7.- ECOS-RUNSALT simulations for constant temperatures of 0,15 and $30^{\circ} \mathrm{C}$ and variable relative humidity. The salts in the crystal form are presented in different colours according to the chart legend. The black line represents the sum of the volumes of the different crystallized salts present. 
To understand if there were environmental conditions in the "Study room" that might have triggered events of weathering of the column material, the results for all the simulations were analysed in terms of rise and decline of the relative humidity for each computed temperature. Figure 8 shows all the plots of total salt volume against relative humidity for the various temperatures ranging from $0{ }^{\circ} \mathrm{C}$ to $40^{\circ} \mathrm{C}$. [Figure 8]

When the simulations are analysed from the perspective of rising relative humidity, there is only two observed episodes of increasing total salt volume at $15^{\circ} \mathrm{C}$ and at $20^{\circ} \mathrm{C}$. For example, at $15^{\circ} \mathrm{C}$, the total salt volume increases when the relative humidity rises from $15 \%$ to $16,66 \%$ (red arrow). In the case of the decline of the relative humidity perspective (blue arrow), in every chart, we can see that there is always a rise of the total salt volume starting at $63,14 \%$ of relative humidity until different values of relative humidity, depending on the studied temperature. For example, at $0{ }^{\circ} \mathrm{C}$, the total salt volume increases until $24,96 \%$ of relative humidity. This rise, from the perspective of the decline of the relative humidity, has several steps but never decreases, it otherwise couldn't be approached as a single rise episode, but that there are declining relative humidity zones where the rise of the total salt volume is negligible. For example, in the $15^{\circ} \mathrm{C}$ chart, there is a level of almost non varying salt volume when the relative humidity declines from $56 \%$ to $43 \%$, while for the same temperature there is a huge increase in salt volume when the relative humidity declines from $25 \%$ to $23 \%$. This means that some values of relative humidity are more prone to develop increase in total salt volume than others. This characteristic behaviour is of great interest in the scope of the control of the weathering. If the environmental conditions are controlled within certain boundaries that restrain the increase of the salt volume, the occurrence of weathering phenomena can also be controlled.

Analysing the episodes of rising total salt volume and plotting their starting and ending slope values of the relative humidity versus the temperature, we will obtain a chart of bands of environmental conditions in which the weathering will take place (Menéndez 2017: 22-30). In Figure 9, the chart of the weathering conditions for the limestone base material of the studied column is presented and added with a collection of dots representing the daily episodes of increasing and
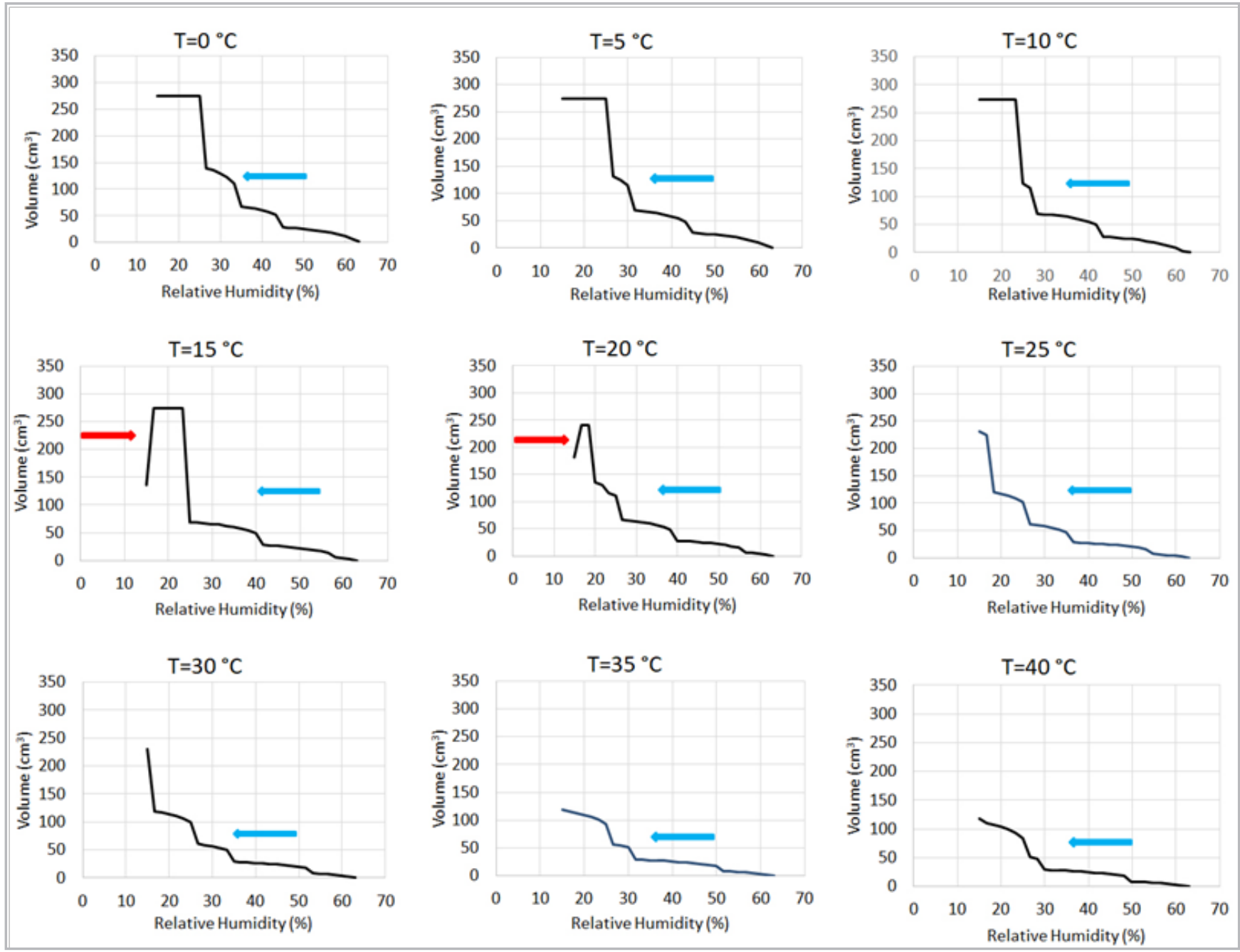

Figure 8.- Total salt volume and relative humidity at the studied temperatures. The red arrow indicates the conditions of total salt volume increase when the relative humidity rises and the blue arrow indicates the conditions of total salt volume increase when the relative humidity declines. 
of decreasing relative humidity according to the daily data obtained inside the "Study room" where the weathered column stands. The collected environmental data does not span thru a full year but only from late October to midJune. It encompasses the wettest months but not the driest ones. Between 20 and 22 measurements of temperature and relative humidity were taken each day and that data was used to calculate daily average temperature and average relative humidity. The daily average relative humidity was compared with the previous day average to find out if this variable suffered rise or a decline.

The data collected spawns for a total of 230 days of which the relative humidity declined in 113 and rose in 117 days. Since the conditions for weathering when the relative humidity rises are a very narrow band of relative humidity between $15 \%$ and $16,6 \%$ and only when those values of rising relative humidity occur between the temperature of $15^{\circ} \mathrm{C}$ and $20^{\circ} \mathrm{C}$ (see red lines in Figure 9). These values will hardly occur in the Portuguese climate and thus, we opted for not including the data points referring to the relative humidity rise because environmental conditions measured were too far from those values and the chart becomes cleaner and more discernible only with the data points related to the relative humidity decline. [Figure 9]

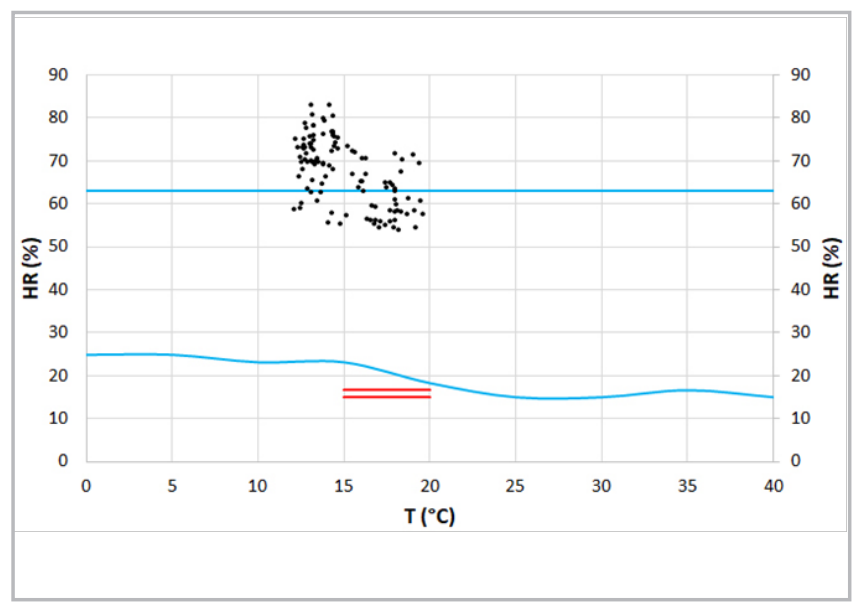

Figure 9.- Results obtained for the model of the weathered column on the "Study room". For each temperature, the blue lines represent the starting and ending values of relative humidity decline that induce salt volume increase. Between the red lines the same conditions for relative humidity rise. The black dots represent the days when relative humidity decline was detected in the Environment of the "Study room".

The black dots data points for the average temperature and average relative humidity corresponding to the days where a decline in relative humidity was detected, denounced that, among the 113 days in those conditions, 39 fell into a region of total salt volume increase shown between the highest and the lowest relative humidity lines (in blue). This means that in about $17 \%$ of all the monitored days, potential weathering could have taken place. In addition, the missing 135 days that roughly correspond to the summer and early autumn (mid-June to late October), are days with lower average relative humidity by comparison with the monitored days (late October to mid-June) and thus, the data points will more easily fall into environmental weathering conditions.

This study, apart from confirming that the environmental conditions theoretically cause weathering events, can also help a conservator-restorer to decide the best temperature and relative humidity values that should help preventing the limestone base material weathering. If the environmental conditions could be kept within certain boundaries of very scarce increase and decrease of salt volume, the weathering could be controlled. In this case, the temperature could be easily kept between $10{ }^{\circ} \mathrm{C}$ and $20^{\circ} \mathrm{C}$ since we know that the maximum and minimum temperatures measured were respectively $20.5{ }^{\circ} \mathrm{C}$ and $11.9{ }^{\circ} \mathrm{C}$. On the other hand, for these temperatures, Figure 8 shows that the increase in total salt volume starts when the relative humidity falls below $63,14 \%$. By controlling the relative humidity at $65 \%$ there will be no increase or decrease in total salt volume, and thus weathering is prevented.

\section{Conclusions}

In this conservative intervention, the aim was to resolve the degradation caused by the local salts, for which it was essential to know its cause and dynamism.

To obtain this in-depth knowledge, the methodological procedures adopted and the analytical procedures carried out were essential. Finally, the submission of the knowledge thus obtained, to this software resource, allowed us to consolidate everything and obtain scenarios forecast regarding the environmental conditions that best favor future conservation.

For now, it is known that by controlling the relative humidity at $65 \pm 2 \%$ in temperatures ranging from $10^{\circ} \mathrm{C}$ to $20^{\circ} \mathrm{C}$ those most harmful weathering events will be prevented, which is an important fact to take into account when maintaining the site.

\section{References}

AIRES BARROS, L., (2002). Modes and mechanisms of rocks weathering. In: Protection and Conservation of Cultural Heritage of the Mediterranean Cities. Balkema Publishers, Lisse (The Netherlands), 3-9.

CARDELL, C., DELALIEUX, F., ROUMPOPOULOS, K., MOROPOULOUS, A., AUGER, F., VAN GREEKEN, R., (2003). Salt-induced decay in calcareous stone monuments and buildings in a marine environment in SW France. Construction and Building Materials 17: 165-179. https://doi.org/10.1016/S0950-0618(02)00104-6

FRANCESCHI, S., \& GERMANI, L. (2005). Manuale operativo per il restauro architettonico: metodologie di intervento per il restauro e la conservazione del patrimonio storico. Tipografia del Genio Civile, 176-178. 
TSUI, N., FLATT, R.J., SCHERER, G.W., (2003). Crystallization damage by sodium sulphate. Journal of Cultural Heritage 4:109-115. https:// doi.org/10.1016/S1296-2074(03)00022-0

ARNOLD, A., ZEHNDER, K., (1990). Salt weathering on monuments. In: I International Symposium on the Conservation of Monuments in the Mediterranean Basin, Bari, Italy, 31-58.

FITZNER, B., (1994). Porosity properties and weathering behaviour of natural stones. Methodology and examples. In: Stone Material in Monuments: Diagnosis and Conservation. Second Course, University School of Monument Conservation, Bari, Italy, 43-54.

BENAVENTE, D., GARCÍA DEL CURA, M.A., FORT, R., ORDÓÑEZ, S., (2004). Durability estimation of porous building stones from pore structure and strength. Engineering Geology 74: 113-127. https:// doi.org/10.1016/j.enggeo.2004.03.005

CHAROLA, A. E., (2000). Salts in the deterioration of porous materials. An overview. Journal of the American Institute for Conservation 39: 327-343.https://doi.org/10.1179/019713600806113176

DOEHNE E, SELWITZ CX, CARSON D, DE TAGLE A. (2001) Damage to monuments from the crystallization of mirabilite, thenardite and halite: mechanisms, environment and preventive possibilities. In: 11 th annual V.M. Goldschmidt conference.

HONEYCOMBE DB., (1990). Weathering and decay of Masonry. In: Conservation of building and decorative stones. 1998 edition. Oxford: Butterworth/Heinemann; 153-178.

BRIMBLECOMBE P, GROSSI CM. (2007). Damage to buildings from future climate and pollution. APT Bulletin J Preservation Technology; XXXVIII (2-3): 13-8. https://www.researchgate.net/ publication/271846514 Damage to Buildings from Future Climate and Pollution

RUIZ-AGUDO E, LUBELLI B, SAWDY A, VAN HEES R, PRICE C, RODRIGUEZ-NAVARRO C. (2010). An integrated methodology for salt damage assessment and remediation: the case of San Jerónimo Monastery (Granada, Spain), Environmental Earth Sciences; 63 (7-8): 1475-1486. https://doi.org/10.1007/s12665-010-0661-9

GOUDI, A.S., VILES, H.A. (2008). Weathering processes and forms, in: T.P. Burt, R.J. Chorley,D. Brunsden, N.J. Cox, A.S. Goidue (Eds.), The History of the Study of Landformsof the Developement of Geomorphology, 4 Quaternary and Recent Pro-cesses and Forms (1890-1965) and the Mid-century Revolutions, GeologicalSociety, Bath, UK, 129-164.

STEIGER, M. AND HERITAGE, A. (2012). Modelling the crystallization behaviour of mixed salt systems: input data requirements. 12th International Congress on the Deterioration and Conservation of Stone, Columbia University, New York. http://iscs.icomos.org/pdffiles/NewYorkConf/steiheri.pdf

PRICE, C.A., (2007). Predicting environmental conditions to minimize salt damage at the Tower of London: a comparison of two approaches. Environmental Geology, 52: 369-374. https://link. springer.com/article/10.1007/s00254-006-0477-9

BIONDA, D., (2005). RUNSALT computer program, 2002-2005 http:// science.sdf-eu.org/runsalt/

PUIM, P., GONÇALVES, T. D., BRITO, V., (2012). Controlo e prevenção de anomalias devidas à cristalização de sais solúveis em edifícios antigos. Em Actas do $4^{\circ}$ Encontro sobre Patologia e Reabilitação de Edifícios - PATORREB 2012, Santiago de Compostela, 2. http://wwwext.Inec.pt/drymass/pdfs/PP TG VB Patorreb.pdf

WINKLER, E., (2013). Stone in architecture: properties, durability. Springer Science \& Business Media, 155-156. https://www.springer. com/gp/book/9783642451546

FRANZIN, I., (2009). "La risalita capillare: il fenomeno della cristallizzazione salina a Venezia." Con particolare riferimento al marmo bianco di carrara, la pietra d'Istri ae il marmo rosso di Verona, Corso di collaboratore restauratore dei beni culturali, Universita'Internazionzle dell'Arte, Venezia , 12. https://www. yumpu.com/it/document/read/16230078/il-fenomeno-dellacristallizzazione-salina-a-venezia-universita-

LUBELLI, B., \& VAN HEES, R. P. (2007). Effectiveness of crystallization inhibitors in preventing salt damage in building materials. Journal of cultural heritage, 8(3): 223. https://doi.org/10.1016/j. culher.2007.06.001

Norma UNI 10829:1999 Beni di interesse storico e artistico Condizioni ambientali di conservazione. Misurazione e analisi, 1-20.

APHA, (1992). Method 4110: Standard Methods for the Examination of Water and Wastewater, American Public Health Association, Code of Federal Regulations: 40 CFR 136.3(a), Washington. I

ISO 11885:2007 Water quality - Determination of selected elements.

SILVA B, RIVAS T, GARCÍA-RODEJA E, PRIETO B. (2007). Distribution of ions of marine origin in Galicia (NW Spain) as a function of distance from the sea. Atmos Environ; 41:(4) 396-407. https://doi. org/10.1016/j.atmosenv.2007.01.045

LANAS, J., \& ALVAREZ-GALINDO, J. I. (2003). Masonry repair limebased mortars: factors affecting the mechanical behavior. Cement and concrete research, 33 (11): 1867. https://doi.org/10.1016/ S0008-8846(03)00210-2

MENÉNDEZ, B., (2017). Estimation of salt mixture damage on built cultural heritage from environmental conditions using ECOSRUNSALT model, Journal of Cultural Heritage, 24: 22-30. https:// doi.org/10.1016/j.culher.2016.11.006 


\section{Author/s}

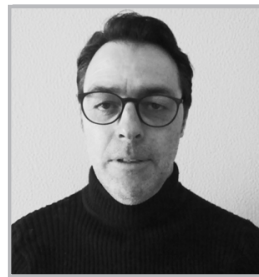

\section{Fernando Manuel da Conceição Costa}

fmccosta@ipt.pt

Techn\&Art - Technology, Restoration and Arts Enhancement Center, Instituto Politécnico de Tomar

https://orcid.org/0000-0002-2726-1679

Professor Adjunto do Instituto Politécnico de Tomar, Investigador Integrado do Techn\&Art - Centro de Tecnologia, Restauro e Valorização das Artes. Responsável do laboratório de Conservação e Restauro de Pedra. Professor Especialista Artes Conservação e Restauro. Mestre em Recuperação do Património Arquitetónico e Paisagístico pela Universidade de Évora.

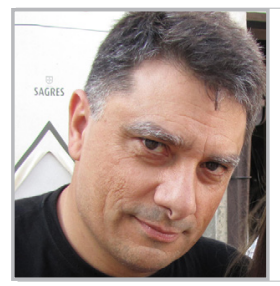

Manuel Alberto Nogueira Henriques Rosa manuel.rosa@ipt.pt

Techn\&Art - Technology, Restoration and Arts Enhancement Center, Instituto Politécnico de Tomar https://orcid.org/0000-0003-0768-6714

Licenciado pelo Instituto Politécnico de Tomar em Engenharia Química Industrial, especialização em Tecnologia, Mestre pela Universidade de Aveiro em Métodos Instrumentais e Controlo de Qualidade Analítico e Doutor em Ciências Ambientais pela Universidade de Salamanca. Profissionalmente foi Professor Auxiliar de 2003 a 2016 e Professor desde 2016. Foi Diretor dos Cursos Associados / Fundamentais em Qualidade Ambiental de 2013 a 2019. É membro do Centro de Tecnologia, Restauração e Aprimoramento de Arte (Techn \& Art), IPT e publica artigos científicos revisados por pares e desenvolve trabalhos científicos nas áreas de degradação por ação de sais em edifícios e esculturas de pedra.

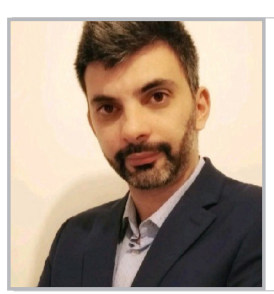

\section{Mattia Canetto}

canettomattia@gmail.com

University of Cagliari, Faculty of Engineering and Architecture, Italy

Formou-se em Arquitetura pela Universidade de Cagliari e fez mestrado em Conservação do Património Arquitetónico e Ambiental pela Universidade de Cagliari.

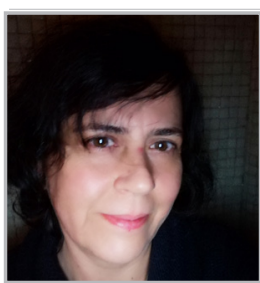

Maria Júlia Sobral da Fonseca

juliafonseca.fcul@gmail.com

Projetista de Conservação e Restauro em Património Imóvel Classificado https://orcid.org/0000-0002-2043-8304

Licenciada em Conservação e Restauro de Pedra e Mestre em Química Aplicada ao Património Cultural. Foi conservadorarestauradora no Mosteiro de Santa Clara-a-Velha (Coimbra) e Mosteiro de S. João Tarouca (Lamego) e também bolseira da
Fundação para a Ciência e Tecnologia. Atualmente é projetista de Conservação e Restauro em Património Imóvel Classificado (Portugal)

Artículo enviado el 17/09/2021 Artículo aceptado el 10/01/2022

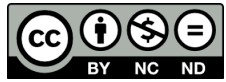

https://doi.org/10.37558/gec.v21i1.1052 